\title{
冷却による実験的顔面神経麻痺の回復過程の組織学的検討
}

\author{
神戸大学医学部耳鼻咽喉科学教室（主任；天津睦郎教授） \\ 細 見 慶 和
}

\section{HISTOPATHOLOGICAL STUDY OF THE RECOVERY PROCESS IN EXPERIMENTAL FACIAL NERVE PALSY INDUCED BY FREEZING}

\author{
YOSHIKAZU HOSOMI, M.D.
}

Department of Otolaryngology, Head and Neck Surgery, Kobe University, School of Medicine, Kobe

The facial nerve has a specific anatomical feature in that it pursues a relatively long course through a bony canal, originating in the fundus of the internal auditory meatus, until emerging at the stylomastoid foramen.

Facial nerve palsy, which is often observed clinically, exhibits a high recovery rate of facial movement. There is no consensus, however, as to the influence of the anatomical features of the facial nerve on the pathological evolution of the palsy. The purpose of this study is to investigate how histological alterations, following injury of the nerve, are influenced by the anatomical feature mentioned above.

Mongolian gerbils, weighing $60 \mathrm{~g}-90 \mathrm{~g}$, were used. Facial nerve palsy was induced by freezing the tympanic part of the facial nerve. Myringotomy was then performed using mícroscope. The middle ear space was frozen at $-2^{\circ} \mathrm{C}$ to $-8^{\circ} \mathrm{C}$ for 30 seconds through perforation with dimethylether liquid propane gas. Facial nerve palsy was confirmed by loss of the blink reflex and whisker movement. Specimens were removed from the tympanic part of the facial nerve, embedded in epon, and the sections were examined under light and electron microscopy.

Out of 16 ears (13 animals) thus frozen, $15(94 \%)$ exhibited complete facial palsy. Facial movement recovered within the 21-to 35-day period after freezing. At thirty-six hours after freezing, thin regenerating axons were seen in Schwann cell basal lamina scaffolds. Even on the seventh day after freezing, when connective tissue around the nerve trunk was thickest, regenerating axons continued to grow and did not degenerate. In the 21-to 35-day period after freezing, regenerating axons were myelinated and mature.

Once the facial nerve is injured in a fallopian canal, regenerating axons are soon formed and continue to grow even in the presence of degenerated nerve fibers and thickened connective tissue. No distinct degenerative behavior is observed in these regenerating axons. From these findings, it is suggested that nerve fibers may not degenerate even in the presence of injured nerve fibers in the bony canal.

Key words : 顔面神経麻㾝, 砂ねずみ, 冷却, 光顕, 電顕 A $97-1683-91531$

\section{緒霉}

ヒトの顔面神経は内耳道底から茎乳突孔にいたる部 分を顔面神経管と呼ばれる骨性の管に取り囲まれてい
る122．このように顔面神経は骨に囲まれた経路が長い という走行の特異性をもっている゙.

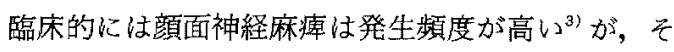


の一方で顔面神経麻瘦は高率に治瘾することも知られ ている(1〜7). 解剖学的には顔面神経の易障害部位は内

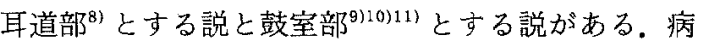
理学的には神経幹周囲組織の肥厚や神経の浮腫, 出血, 炎症やウイルスの関与を括もかせるものなど(2)131144が ある。このように顔面神経麻瘦については種々の報告 がなされているが，顔面神経の走行の特異性との関連 についてはいまだに定説は得られていない。

神経線維に障害が起きた際に神経幹が骨によって制 限された空間内に存在しているためにその変性や再生 の過程がどのように影響されるのかを組織学的に明ら がにることは顔面神経麻㽻を理解するうえで重要で ある。このためには骨性の枠組みを破壊することなく 麻痺を発症させ，その経過を経時的に観察することが 必要である. 顔面神経管を保存した上で顔面神経管内 で神経障害が，どのような過程をたどるのかについて の研究は虚血によるもの ${ }^{15116)}$, ウイルスによるもの ${ }^{173}$ 等がある. しかし，麻痺発症早期から顔面運動回復に いたるまでの微細構造の変化については不明である。

著者は, その構造上，側頭骨内に㤝いて顔面神経の

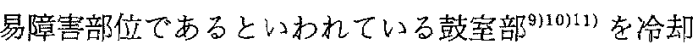
することによって顔面神経管の構造を保ちつつ高率に 顔面神経麻痺を惹起し，かつ一定の回復傾向を示す砂 ネズミを用いたモデルを作製した ${ }^{19)}$.このモデルを用 いて経時的に顔面運動を観察するとともに, 光学顕微 鏡と電子顕微鏡による観察を行い，顔面神経管内で神 経障害が発生した場合の微細構造の変化についての知 見を得たので報告する。

\section{方法}

砂ねずみ（体重約 $60 \mathrm{~g}$ 加ら $90 \mathrm{~g}$ )を用いた，取り扱い は神戸大学動物実験規約にのっとって行った、ネンブ タールまたは，ケタラールで麻酔を施し，顕微鏡下に 鼓膜切開を行い切開空から中耳腔内に DME.LPG（ジ メチルエーテル加液化プロパンガス）を噴霧し顔面神 経管を冷却した ${ }^{19}$ ，冷却時の中耳腔内の温度は微細温 度センサー（ニューロサイエンス社製）を用いて電子 温度計（佐藤計量器製作所製温度計；SKI250MC，ま たはタスコジャパン株式会社製；TNA-120)でモニ夕 一した。

これまでの実験結果に基づき ${ }^{19)}$ 中耳腔内を約30秒 閒約マイナス $2^{\circ} \mathrm{C}$ から $8^{\circ} \mathrm{C}$ になるように冷却を行っ た。この条件下での顔面神経管内の温度変化の把握の ために 1 匹（2 側）では観血的に顔面神経本幹を側頭
骨外で露出し，側頭骨を一部削開し，顔面神経管攱室 部に微細温度センサーを㨓入して温度を測定した。温 度測定中は周囲筋組織などの周囲組織を用いて側謴骨 削開部を閉鎖した。

顔面神経麻痺については, 冷却後, 瞬目反射と㩆運 動の消失をもって発症を確認した，13匹の16耳に冷却 を行い，顔面神経麻㾇の発症を確認した15側の顔面神 経と顔面神経を泠却しなかった 4 侧を対照として組織 学的検討に用いた。先行䛶験 ${ }^{19)}$ では, この冷却条件で 冷却後21日目汃ら35日目で顔面運動は正常となってい たため，本研究では冷却直後，3時間，36時間，3日， 5 日，7日，21日，35日後の顔面神経を各 2 側ないし は 1 側ずつ採取した（表 1 )。ネンブタールで十分に麻 酔後, 開胸し左心室から生理食塩水で灌流し, カル， フスキー液で灌流固定を行った。側頭骨を削開し，さ らにカルノフスキー原液で浸漬固定した後，10\% EDTA (Ethylene diaminete traacetic acid) 液て脱 灰し, リン酸緩衝液 $(\mathrm{pH} ; 7.4$ ) で洗浄後, 顔面神経を 鼓室部で約 $1.5 \mathrm{~mm}$ を顕微鏡下に採取し，四酸化才又 ミウム液で 2 時間後固定を行った，エタノール系列で の脱水後，型のごとくエポン樹脂に包埋した，厚さ約

表 1

\begin{tabular}{|c|c|c|}
\hline 砂ねずみ & 右側顔面神経 & 左側顔面神経 \\
\hline 1 & $(-)$ & 麻痺 (直後) \\
\hline 2 & $\mathrm{C}$ & 麻痖 ( 3 時間) \\
\hline 3 & $\mathrm{C}$ & 麻盘 (36時間) \\
\hline 4 & $\mathrm{C}$ & 麻㽻 ( 3 日) \\
\hline 5 & $(-)$ & 麻瘏 ( 3 日) \\
\hline 6 & 麻㯅 ( 3 時間) & 麻摩 (5 日) \\
\hline 7 & $\mathrm{C}$ & 麻㾝 ( 7 日) \\
\hline 8 & 麻猈 (直後) & 麻疸 (7日) \\
\hline 9 & $(-)$ & 麻疩 (21日) \\
\hline 10 & 麻痖 (21日) & $(-)$ \\
\hline 11 & $(-)$ & 麻瘒 (35日) \\
\hline 12 & 麻㯅 (直後) & 麻痺 (35日) \\
\hline 13 & $(-)$ & 麻㽻発症せず \\
\hline
\end{tabular}

C ; 対照

麻痺（）; 麻瘴発症あり, カッコ内は冷却後組織採 取時期

(一) ; 使用せず

注 ; 動物 6，8，12は，灌流固定時間をあら かじめ定めておき，そこから逆算して左 右それぞれ異なる時点で冷却を行った。 灌流固定以後は左右同時に標本処理を行 った. 


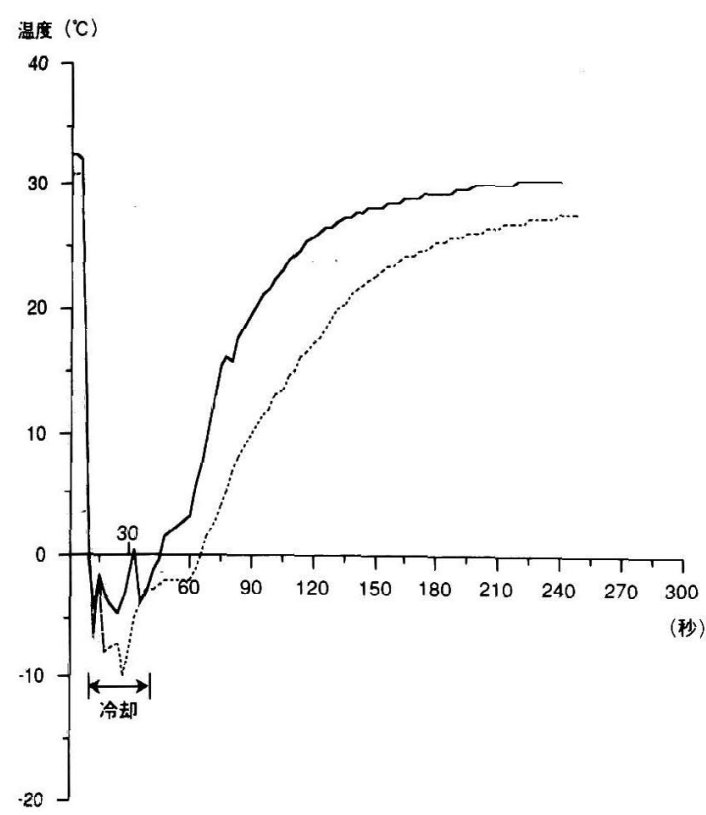

図 1 中耳腔冷却時の顔面神経管内温度変化左 右それぞれの温度変化を示す。 （左側；実線，右側；点線）

$0.5 \mu \mathrm{m}$ の準薄切切片はトルイジンブルー染色を施し， 光学顕微鏡で神経幹と周囲結合織, 顔面神経管との関 係に注目しながら観察した。また超薄切切片はウラン と鉛の二重染色を施し神経幹内の微細構造の变化を電 子䫓微鏡で観察した.

\section{結果}

1. 鼓室内温度変化

鼓室内に DME. LPG を噴霧して冷却した時の顔面 神経管内の温度変化を図 1 亿示す. 顔面神経管内の温 度は急速に低下し, マイナス約 $2{ }^{\circ} \mathrm{C}$ から $8^{\circ} \mathrm{C}$ 状態が 約 30 秒間持続し, 噴霧終了後加温度は急速に上昇し 冷却開始から180秒から240秒後にはほほ体温のレベル まで戻っていた。

\section{2. 顔面運動の観察}

今回の実験では13匹，16側に冷却を行い，15側（94 \%)で顔面神経麻痺発症を確認した。

冷却後, 経時的に瞬目運動と髹運動を指標に顔面運 動を観察した．冷却後 7 日目までは顔面運動に回復は 認められなかった，21日目，35日目で灌流固定を行っ た 4 匹では全例において顔面運動に左右差は認められ ず, 顔面運動は回復していた。

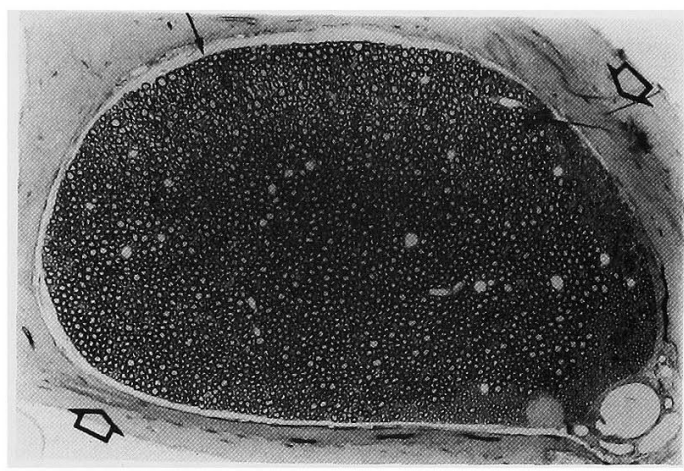

図 2 正常顔面神経と顔面神経管; 光顕像 $(\times 60)$

神経上膜 $(\rightarrow)$ と顔面神経管 $(\Rightarrow)$.

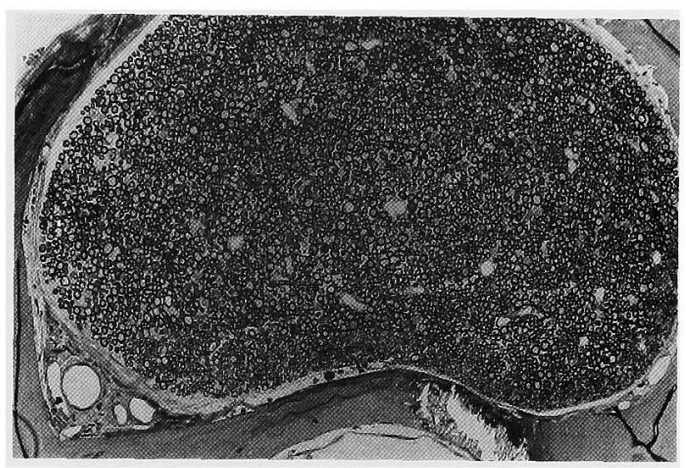

図 3 冷却後 3 時間; 光顕像 $(\times 60)$ 顔面神経管と神経幹の間の結合織，およ び神経幹内の変化は軽微である。

3. 光学顕微鏡による観察

1）正常像；顔面神経管内鼓室部での顔面神経の径 はおよそ $0.7 \times 0.3 \mathrm{~mm}$ で神経周膜はみられず全体で ひとつの神経線維束を形成していた。神経上膜は薄く, 顔面神経管と神経幹の間には非常に狭く疎な間隙が認 められた．神経幹内では正门形の有髄線維が密に配列 し, 径の細い神経線維が神経幹の表層部分に多い傾向 が認められた。神経上膜と神経幹内には小血管も散在 性に分布していた（図 2).

2）冷却直後および冷却後 3 時間; 光学顕微鏡で観 察した範囲では神経幹内には著明な変化は認められな かった、神経幹周囲組織にはわずかに肥厚も見られた が神経幹と神経管の間には疎な間隙が存在していた (図 3).

3）冷却後 36 時間; 神経幹内で神経線維と神経線維 0)間に不規則な間隙が認められた，髄鞘に変化がある 


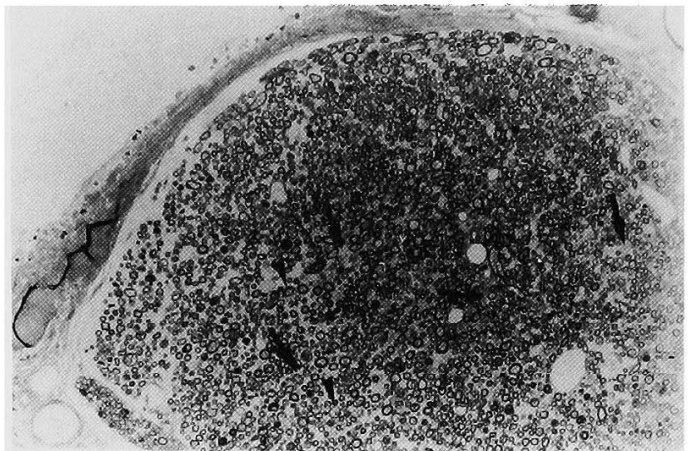

図 4 冷却後36時間; 光顕像 $(\times 60)$

変性に宿つた䯣䩪（一）と神経線維間に 間隐が出現している (

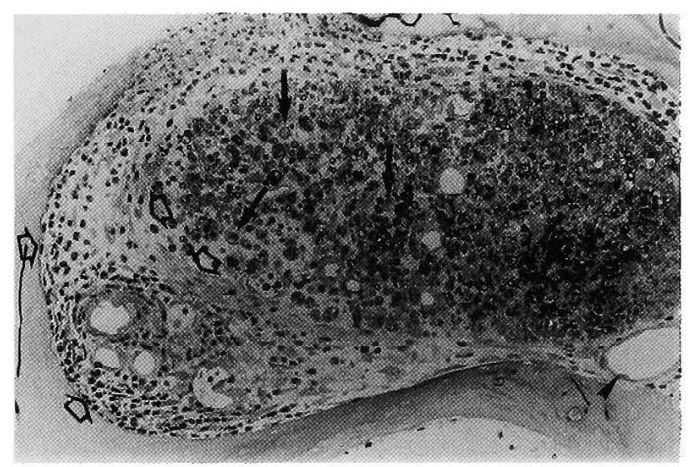

図 5 冷却後 3 日目; 光顕像 $(\times 60)$ 神経幹内では神経線維がまばらになり， 神経管内での神経上膜や結合織の肥厚が 著明である。( ( )。破壞された髄鞘 $(\rightarrow)$ と拡大した血管（一)。

ものも認められた。また，神経幹周囲の結合織も少し 厚くなっていたが, 細胞成分には特に変化はみられな かった（図 4 ).

4）冷却後 3 日目，5日目；神経幹内では神経線維 間の間隙が増大しており, 䑷鞘の多くは破壤され, 正 常な神経線維の構造を持つ神経線維はほとんどみられ なかった。神経幹周井の結合織も著明に厚くなってお り，円形の細胞成分が多数認められた。また神経幹内 や周囲結合織内の血管内腔が著しく拡大していた (図 5 ).

5）冷却後 7 日目; 残存する䯣鞘はほとんどなく, 破壊された髄䩪は除去されている。神経幹内には明る い卵円形の細胞が多数散在し, 著明に肥厚した神経幹 周囲の結合織にも多数の円形細胞が認められた。また

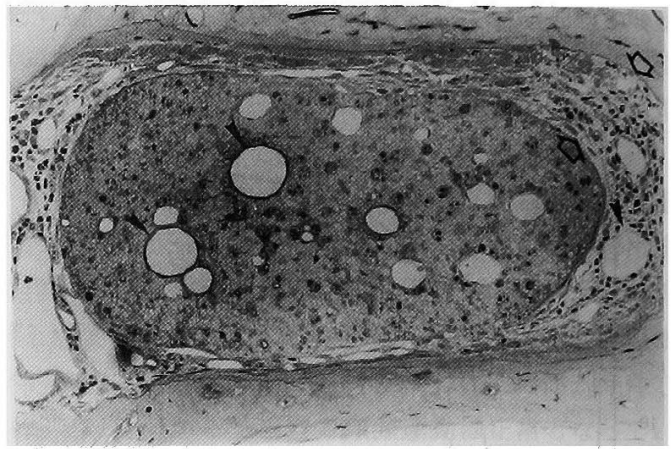

図 6 冷却後 7 日目; 光顕像 $(\times 60)$ 正常神経構造注破壊され, 顔面神経幹と 顔面神経管の間は肥厚した結合織で満た され (の) 血管内腔は㹡大している(一).

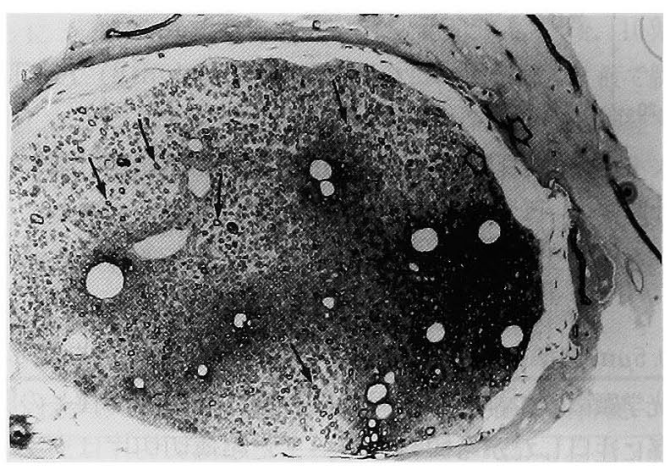

図 7 冷却後21日目; 光顕像 $(\times 60)$ 再生神経線維が出現し $(\rightarrow)$, 神経幹周囲 結合織の肥厚も減少してきている $(\Longleftrightarrow)$.

神経幹内や周囲結合織内の血管はさらに拡大していた (図 6).

6）冷却後21日日；髄鞘を持つ神経線維が散在性に 認められたが正常のものに比べると明らかに細い. 神 経幹周囲の結合織は冷却後 7 日目に比べて薄くなって おり, 細胞成分も著しく減少していた。神経幹内およ び周囲結合織内の血管内腔も正常に比べて拡大してい るものの冷却後 7 日目に比べると細くなっていた (図 7 ).

7）冷却後35日目；有髄神経線維は21日目よりもさ らに増加しており，線維間の間隙も縮小していた。 神 経幹周井の結合織は薄くなっており，血管内腔は正常 よりも拡大してはいるが21日目に比べて縮小していた (図 8).

4. 電子顕微鏡による観察 


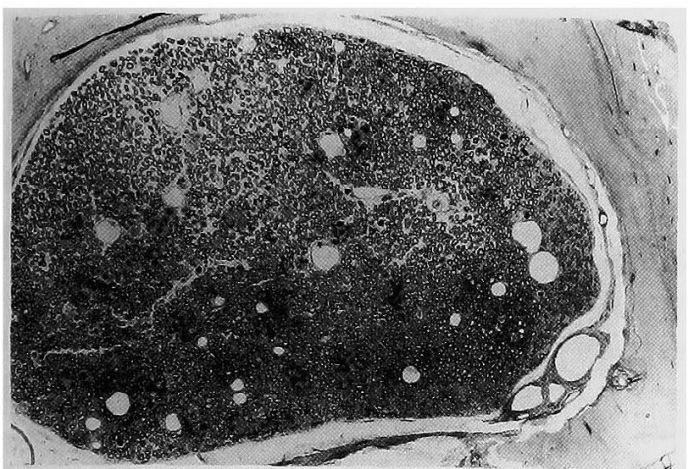

図 8 冷却後 35 日目; 光顕像 $(\times 60)$ 正常神経に近い構造になってきている.

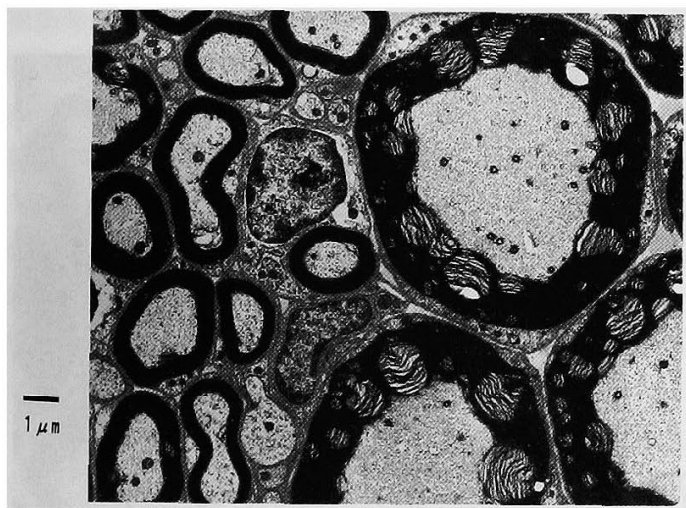

図 9 正常顔面神経; 電影像 $(\times 6000)$

1）正常像；神経幹表層付近における像を示す。有 䯣神経に太いものと細いものがあり，無髄神経も散見 される.シュワン細胞も見られる（図 9 ）。

2）冷却直後, 冷却後 3 時間; 神経幹表層部では太 い有髄神経線維の髄鞘の層構造が高度に乱れ，軸索と 㵦鞘の解離や，神経細糸の凝集，ミトコンドリアの膨 化変性が認められた。シュワン細胞や血管内皮細胞に は，冷却によって細胞が傷害されたことを示唆する細 胞質の部分的な融解も観察された。しかし神経幹の中 心部ではこのような形態変化は軽微であった（図10).

3）冷却後36時間；神経幹の全体にわたって有髄神 経の䚛鞘の乱れは高度となり，軸索がまったく融解し てしまったものや, 軸索と㵦鞘の高度な解離, 神経細 系の凝集や，ミトコンドリアの変性を示すものが認め られた. 生存していると思われるシュワン細胞はほと んど認められなかった。しかし，変性した髄鞘とシュ ワン細胞の基底膜との間には, 細い再生軸索が散在性

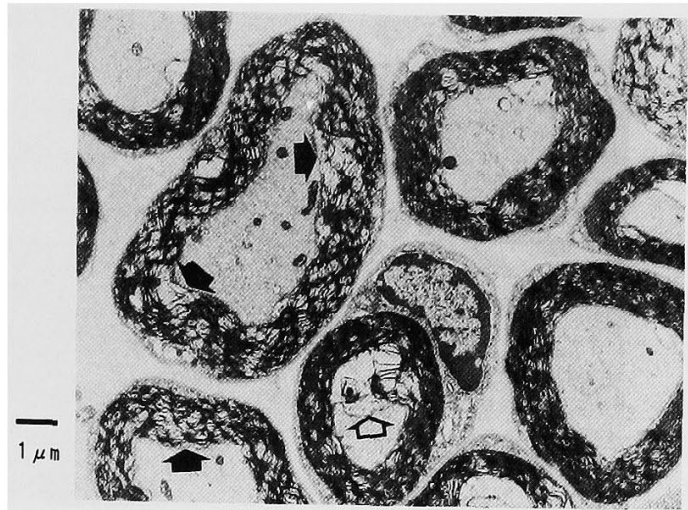

図10 冷却直後; 電顕像 $(\times 6000)$ 神経幹表曆近くでの像である。䯇靽構造 の乱れがある $(\rightarrow)$ ．既に軸索と髄鞘が解 離しているものも見られる $(\Rightarrow)$.

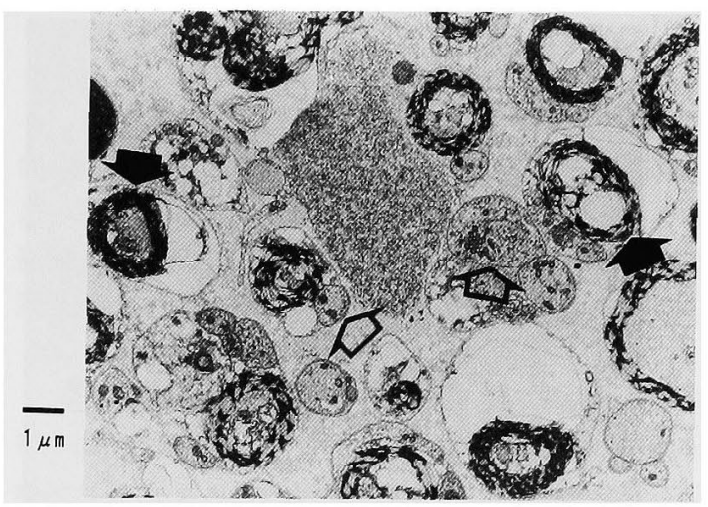

图11 冷却後36時間; 電顕像 $(\times 6000)$ 髄鞘構造は高度に破壊されている $(\rightarrow)$. ひとつの基底膜筒内に破壊された䯑道鞘と 再生神経が見られる(

に認められた。これらの再生軸索は成長円錐に近いこ とを示す直径が 50 から $100 \mathrm{~nm}$ の多数の小胞やいくつ かの小型のミトコンドリアを含んでいた。多くの血管 内皮細胞でも細胞質が融解したり暗調になっていた (図11).

4）冷却後 3 日目, 冷却後 5 日目；マクロファージ が遊走してきて扔り変性した髄鞘を盛んに貪食してい た。変性した髄鞘の中は空虚で, 軸索は完全に融解し ていた，変性した神経線維の間には，髄鞘が除去され て基底膜だけになった筒が存在し，その中には多数の 再生軸索が認められた。個々の軸索は正常の有髄神経 よりも細く, 数本が共通の基底膜の中で線維束を形成 


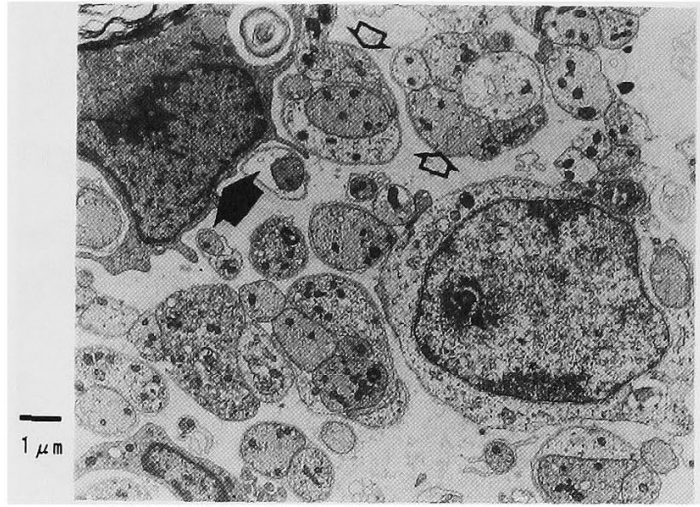

図12 冷却後 5 日目；電顕像 $(\times 6000)$ 一つの基底膜筒内にある複数の再生軸索 $(\Longleftrightarrow)$ と変性した䯠鞘を貪食するマクロフ アージ $(\rightarrow)$.

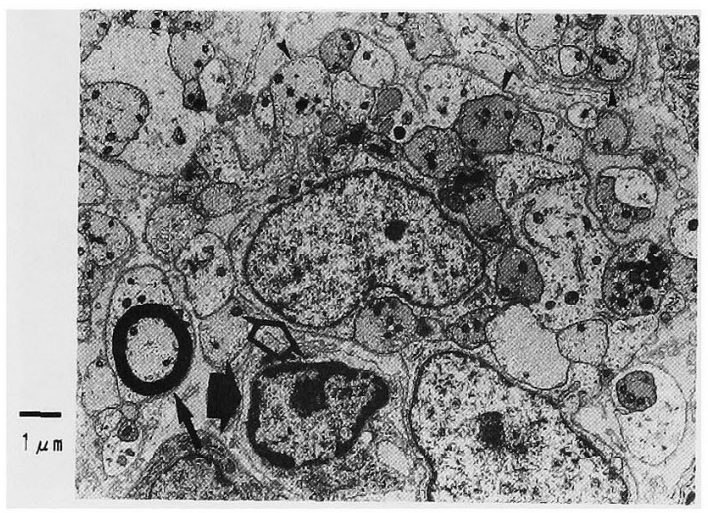

図13 冷却後 7 日目; 電䫓像 $(\times 6000)$ 多数の再生神経線維がひとつの基底膜筒 内にみられる(つ). 近くにはシュワン細 胞も見られる $(\Leftrightarrow)$. 再生された細い有䯣 線維も認められる $(\rightarrow)$. マクロファージ も存在する $(\rightarrow)$.

していた。なかには多数の小胞とミトコンドリアを含 む成長円錐もみられたが，多くは整然と配列した神経 細系や微細管を含む再生軸索であった，また大きな明 るい核と豊富な細胞質をもち,これらは細胞質の突起 で再生軸索を包もうとしていることからシュワン細胞 であると考えられる細胞が散見された。神経幹内では 血管壁の細胞は細胞質に変化もみられたが融解等の形 態破壊は認められなかった（涵12）。

5）冷却後 7 日目; 再生軸索はさらに增加してい た. 再生軸索の何本かがひとつの基底膜筒のなかで軸

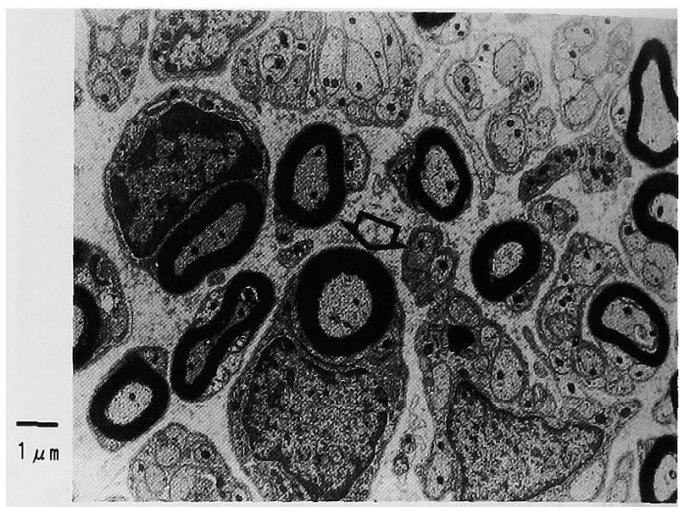

図14 冷却後21日目；電顕像（×6000） 紲い有髄線維の出現 $(\Rightarrow)$.

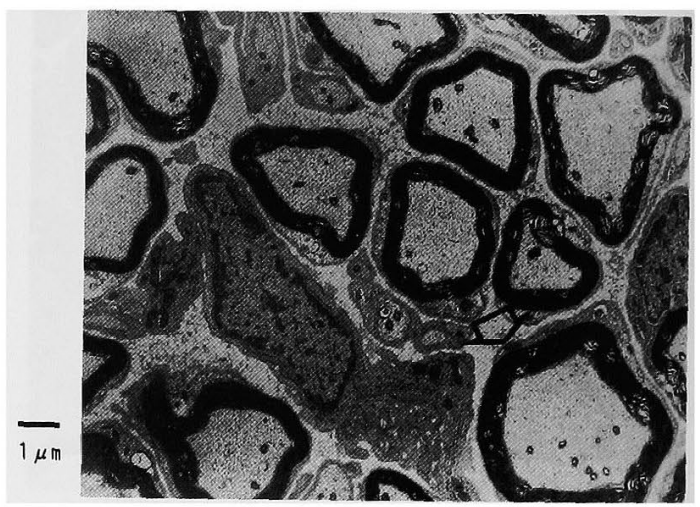

図15 冷却後35日目；電䫓像 $(\times 6000)$ 有髄神経の髄鞘が厚くなり直径も大きく なり正常に近くなっている (

索束を形成して抢り，軸索束と軸索束は接して㧈り密 に存在していた。これらの再生軸索に変性像はみられ なかった. 軸索は長軸方向に走る神経細糸や微細管, ミトコンドリアや滑面小胞体で満たされており，シュ ワン細胞は細い突起を複雑に軸索と軸索の間にのばし ていた.神経幹内では血管壁の細胞破壊は認められず， 血管内腔は保たれていた（図13）。

6）冷却後21日目；いくつかの再生軸索においてシ ュワン細胞による髄鞘の再形成がみられた。ひとつの 髄鞘に囲まれた軸索は無髄の軸索に比べると明らかに 太いが正常の軸索よりは細いものが多かった。再生軸 索の数は冷却後 7 日目（図13）と比べて明らかに減少 しており, 各神経線維や神経線維束の間の距離は広く なっていた（図14）。

7）冷却後35日目；有髄神経はさらに增加し，冷却 
後21日目に比べて軸索は太く榷鞘も厚くなっていた。 一方で無髄神経束は著明に減少していた（図15）。

\section{考 察}

1. 冷却法について

顔面神経管の構造を破壊することなく，簡単かつ高 率に顔面神経における易損傷部位といわれている鼓室 部 ${ }^{91112)}$ に麻痺発症の主な要因をもち，一定の回復傾 向を示す顔面神経麻瘦を若起させることを目的として 鼓室内を冷却する方法を用いた。

一般に末梢神経が傷害されると損傷部付近の神経線 維は損傷変性に，それより末梢側はワーラー変性に陥 る.一方, 損傷変性部位よりも中枢側では, 主として 損傷部に近いランビエ絞輪より再生芽が形成され，神 経の再生が始まる ${ }^{20211}$ 。このような神経損傷後の一連 の変化は損傷の種類にかかわらず共通である.しかし， 神経が切断された場合などはシュワン細胞索やシュワ ン細胞の基底膜の連続性が失われるために再生神経は 結合織の中をある程度の距離はのびていくものの, 標 的器官にまでは達することができず，結合組織の中で 神経線維腫を形成することになる。これに対して，冷 却法による神経損傷ではシュワン細胞は死減してもシ ュワン細胞の基底膜は残存し，その連続性は保たれて いる ${ }^{2223) 24)}$. シュワン練胞の基底膜は神経再生の過程 で, 再生軸索を誘導したり，軸索伸長の足場を提供す るなどの重要な役割を演じている22)23)．今回の実験で はこれら基底膜をはじめとして組織の連続性が保たれ た状態での顔面神経管内の神経再生過程を観察するこ とができた。

\section{2. 冷却による神経障害}

冷却直後の軸索や䯇䩪の変化は, 神経乵の中心部で は中耳腔に近い表層側付近に比べて軽微であったが時 間の経過につれて軸索や髄鞘の変化が神経幹全体に及 んだ.これは神経幹の表層付近と中心付近では冷却効 果に違いが生じ切断や結紮挫滅等のときのように神経 幹断面に瞬間的に一様の外力を受けていないために表 甑部付近と中心部での初期における形態変化に違いが 生じた可能性が考えられる。また初期においては神経 幹の中心部では, 冷却の直接的効果は表層部よりも軽 度であったが冷却によって血管の卛縮が起こり，虚血 によって神経線維が変性に陥った ${ }^{25)}$ 可能性も考えら れる.

冷却後, 時間とともに軸索は融解し, 䯣鞘の層の乱 れも著明となった。一般に神経損傷によって軸索膜が
破壊されると，そこからカルシウムイオンが軸索内に 流入し, 蛋白分解酵素を活性化して神経細系や微細管 の分解が起こるといわれている年227728). 本法では顔面 神経管内の温度が最も低くなるときでもマイナス $10^{\circ} \mathrm{C}$ 程度である。この程度の冷却では細胞内外に括いて一 部に水晶が形成されていると考元られる ${ }^{2529)}$. 凍結損 傷においても，水晶によって軸索膜が傷害され，前述 の上うな過程で徐々に軸索内が变性していくものと考 えられる。一方，髄鞘は，これを支持しているシュワ ン細胞が死滅したり，なんらかの原因でシュワン細胞 に拒絶されると徐々に変性に陷る ${ }^{30}$. 今回の実験では 組織は冷却の直接的影響で傷害されたものとさらに虚 血による変性が加わったものの混在する状態であると 考えられ，冷却によって変性した組織によって二次的 に傷害を受けたと思われる神経線維は見いだせず，神 経変性の過程は冷却そのもので規定されるものと考え られた。

変性した髄鞘はマクロファージによって貪食され る. 今回の実験では, 冷却後 3 日目ごろから髄鞘の残 䯚を細胞質内に取り込んだマクロファージが神経幹内 に多数認められるようになり，7日目にはほとんどの 髄鞘が貪食されていた。 そして，シュワン細胞の基底 膜筒だけが残る状態となっていた（図13,14,15）。

3. 神経再生とその経過

マウスの坐骨神経の有髄神経線維の連結損傷の場合 には損傷後数時間以内にランビエ絞輪に再生芽の形成 が始まる ${ }^{23)}$.また,ラットの坐骨神経を結絷した場合に は 3 時間後にはランビエ絞輪に再生芽形成を思わせる 形態変化が観察されたと報告されている31). 神経再生 開始の時期は，動物の種類や傷害の種類によって異な ることは十分考光られる，今回の実験では神経傷害の 範囲が正確には確定できないために，冷却後どれくら いで有髄神経の再生が始まったのかは不明だが，冷却 後36時間で鼓室部内にみられた多数の再生軸索は成長 円錐に近い部分であり，遅くとも冷却後 1 日以内にお そらくランビエ絞輪加ら神経再生が始まったものと考 えられる。冷却後 5 日目から 7 日目では多数の再生軸 索が損傷部位に観察されており，このことは再生神経 は冷却後 5 日目では既に鼓室部を越えて，より末梢側 に達していることを示している。しかし冷却後 7 日目 においても顔面神経麻㾇は残存していることから，こ の時点では再生神経の先端は標的器官にまでは達して いないと考えられる。冷却後21日目では顔面運動に回 復がみられたことから冷却後 7 日から21日の間に再生 
神経は標的器官に達し運動終末を形成していたことに なる。

一般に1本の親軸索からは数本の再生軸索が形成さ れ，それらが一つの基底膜筒のなかで軸索束を形成 $\iota^{32)}$, その内の1.本が標的器官に達して神経終末を形 成すると, 他の軸索はやがて変性に陷り ${ }^{33)}$, 再生軸索に 随伴してきたシュワン細胞は変性しつつある軸索を放

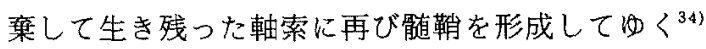
と考元られている.顔面運動と組織像の関係から，今 回の実験において冷却後 7日目加ら21日目に観祭され た再生軸索の隇少はこのような理由によるものである と考えられる. そして, 冷却後 7 日目の再生軸索が標 的器官に達していない時期に扔いても, 再生軸索に変 性所見は認められなかったことから，この時期におけ る再生軸索に対する周囲からの影響による傷害はなか ったと考えられた。

4. 結合組織の反応と血液循環

神経損傷に引き続いて起こる顔面神経管内での結合 組織の反応性肥厚は神経幹を圧迫して血液循環にも悪 影響を及ぼし神経傷害を増悪させ，回復の妨げとなる 可能性も考えられる。しかし，今回の実験では泠却直 後から血管内皮細胞の傷害を示す像があり, 冷却後 5 から7日目で神経幹を取りまく結合織はもつとも厚く なって扔り，神経管と神経幹の間にはこれらの組織が 密に存在したが,この時点で住血管腔はむしろ摭張し 既に多数の再生軸索が伸張してきており，これらの再 生軸索に変性像は認められなかった。 以上の結果から 判断すると顔面神経管内に扔いて今回の実験で認めら れた程度の結合織の反応性肥厚が存在しても血液循環 とシュワン細胞の基底膜は保たれて抢り再生軸索を変 性させるような琹影響はなかったと考えられる。

\section{結語}

1.冷却により一定の回復傾向を示す実験的顔面神 経麻㽻モデルを作製した。

2. 本実験では神経の再生は冷却後 1 日以内に開始 されていたと考えられた。

3. 顔面神経管内では冷却後 5 から 7 日目にかけて 結合織の反応性肥厚がもっとも著明であったが，この 時期に扚いても血液循環とシュワン細胞の基底膜の連 続性㹥保たれ, 神経幹内には多数の再生軸索が存在し て扔り，これら再生軸索に変性像はみられなかった。

4. 以上のことから本実騷においては顔面神経が傷 害を受けた場合, 神経幹が顔面神経管内に存在するが
ゆえに神経線維が周团の影響によって二次的に変性に 陥ったり, 神経再生が悪影響を受ける可能性は低いと 考えられた。

\section{文献}

1) Bernstein L: A surgical approach to the tympanic portion of the facial nerve, with methods of preoperative investigations. Ann Otol Rhinol Laryngol 70: 520-526, 1961.

2) Sunderland S, Cossar DF: The structure of the facial nerve. Anat Rec 116:147-165, 1953.

3）小池吉郎他：ベル麻瘨㧍よびハント症候群の疫学調 查結果, 小池吉郎 他編：特発性顔面神経麻痹に関する 疫学·臨床的研究. 文部省科学研究費補助金総合研究( $(\mathrm{A})$ 研究成果報告書, 1987, 1-31頁.

4) Peitersen E: The natural history of Bell's Palsy. Am J Otol 4 ; 107-111, 1982.

5）小池吉郎, 稲村博雄：ペル麻痺のステロイド早期大量 投与潦法. 耳鼻臨床 81: 1541-1553, 1988.

6) Kinisi $\mathrm{K}$, Amatsu $\mathrm{M}$, Hosomi $\mathrm{H}$ : Conservative treatment of Bell's palsy with steroids and dextran -pentoxiphyllin combined therapy. Eur Arch Otorhinolaryngol 248: 147-149, 1991.

7) Sternnert E : Bell's palsy-New concepts in the treatment. Eur Arch Otorhinolaryngol 225: 265-268, 1979.

8) Fisch U, Felix $\mathrm{H}$ : On the pathogenesis of Bell's palsy. Acta Otolaryngol 95: 532-538, 1983.

9）細見英男，凑川徽，古䦥次夫：末梢性顔面神経麻缯

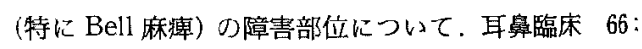
299-305, 1973.

10) Calcaterra TC, Rand RW, Bentson JR: Ischemic paralysis of the facial nerve. Laryngoscope $86: 92$ $-97,1976$.

11）柳原尚明：側頭骨内顔面神経麻瘦にお切る骨性顔面神 経管の意義. 側頭骨内顔面神経麻缯一病態と治療. 宿 題報告モノグラフ1986, 105頁-126頁.

12) Proctor B, Corgill DA, Proud G: The pathology of Bell's palsy. ORL $82: 70-80,1976$.

13) Fernandez JMS, Pormar JMR, Marco $J$ et al: Macroscopic and ultrastructural findings in some disease of the facial nerve. Acta Otolaryngol 83: 211-220, 1977.

14) Michaels L: Histopathological changes in the temporal bone in Bell's palsy. Acta Otolaryngol 
(Stokh) Suppl 470: 114-118, 1990.

15) 竹田泰三，竹田節子，小桜謙一，中谷宏章，斉藤 春雄：虚血性顔面神経麻愺モデル動物に及ぼすグりセ ロールの効果. Facial N Res Jpn 12: 33-38, 1992.

16）里見文男，入谷 實，潜川徹，雲井健雄：虚血性顔 面神経麻瘦の動物モデルにおける $\mathrm{ENOG} と$ 病理所見. Facial N Res Jpn 12:39-42, 1992.

17)杉田俊明：単純へルペスウイルスによる実験的顔面神 経麻㷬に関する研究。日耳鼻 96：685-692，1993。

18) Minatogawa $T$, Kumoi $T$, Hosomi $H$ et al: The blood supply of the facial nerve in the human temporal bone. Auris-Nasus-Larynx (Tokyo) $7: 7$ 18,1980 .

19）練見慶和，大村文秀，木西 實，紐見英男，天津睦郎 他：冷却による実験的顔面神経麻痺モデル。日耳鼻 94: 1622, 1991.

20) Mcquarrie IG: Effect of a conditioning lesion on axonal sprout formation at nodes of Ranvier. J Comp Neurol 231 : 239-249, 1985.

21) Cajal SR: Degeneration and Regeneration of the nervous systems (facsimile of the 1928 edition), Vol 1 , Hafner, London 1968, ppl41-166.

22) Ide $\mathrm{C}$ : Nerve regeneration and schwann cell basal lamina: observations of the long-term regeneration. Arch Histol Jpn 46: 243-257, 1983.

23) Ide $C$, Kato $S$ : Peripheral nerve regeneration. Neurosci Res Suppl 13: 157-164, 1990.

24) 南 仁成, 進 武幹, 渡辺 宏, 前山忠哃, 森川郁郎 他：反回神経の変性及び再生過程の形態学的観察。日 気食会報 $40: 463-468 ， 1989$ 。

25) Douglas WW, Malcolm JL: The effect of localized cooling on conduction in cat nerves. J Physiol 130: 53-71, 1955.

26) Schlaepfer WW: Experimental alteration of neurofilaments and neurotubules by calcium and other irons. Exp Cell Res 67 : 73-80, 1971.

27) Schlaepfer WW, Micko S: Chemical and structural changes of neurofilaments in transected rat sciatic nerve. J Cell Biol 78: 369-378, 1978.
28) Meiri H, Darmann A, Spora ME: Composition of ultrastructural changes in proximal and distal seg. ments of transected giant fibers of the cockroach Periplaneta americana. Brain Res 263: 1-14, 1983.

29) Evans PJD, Lloyd JW, Green CJ: Cryoanalgesia: the response to alterations in freeze cycle and temperature. Br J Anaesth 53: 1121-1127, 1981.

30) Crang AJ, Blakemore WF : Observation on Wallerian degeneration in explant cultures of cat sciatic nerve. J Neurocytol 15: 471-482, 1986.

31) Tomatsuri $M$, Okajima $S$, Ide $C$ : Sprout formation at nodes of Ranvier of crush-injured peripheral nerves. Restoractive Neurol Neurosci $5: 275-282$, 1993.

32) Bray GM, Aguayo AJ : Regeneration of periperal unmyerinated nerves. Fate of the axonal sprouts which develop after injury. J Anat 117:517-529, 1974.

33) Aitken $J$ : The effect of peripheral connexions on the maturation of regenerating nerve fibers. J Anat 83: 32-43, 1949.

34) Cragg BG, Thomas PK: The conduction velocity of regenerated peripheral nerve fibers. J Physiol 171 : $164-175,1964$.

稿を終えるにあたりまして、ご校閲を賜りました天津 睦郎教授に深㝟なる謝意を表します。またっご指導いただき ました木西 實講師に感謝いたします。本研究に際して,ご 協力をいただきました神戸大学医学部第一病理学教室の 伊東 宏教授はじめ教室員の方々，電顕標本作製にご協力い ただいた谷岡慎市文部技官に感謝いたします。また，㤠切な るご助言をいただきよた, 神戸大学医学部第二解剖学教 寀の三木明徳助教授に心から感謝いたします。

(1994年5月10日受稿 1994年7月21日受理 急載) 別刷請求先 $\bar{T} 650$ 神戸市中央区楠町7-5-1 神戸大学医学部耳鼻咽侯科学教室 細見厦和 